\title{
African mediators, the Asante and British colonial rule Introduction
}

\author{
Tom McCaskie
}

In the articles that appear in this issue I offer detailed biographical discussions of the lives of Kwame Tua and Kwasi Apea Nuama. They were full brothers and were born into an independent Asante where they might have expected to pass their lives as servants of the Asantehene in one specialist capacity or another. Like most Africans of their generation, however, their lives were disrupted by the brute fact of colonial overrule, and each followed a markedly different path in coming to terms with the changes - adventitious as well as purposeful - that were wrought by foreign overlordship. As will be seen, the two brothers were singular individuals who crafted very different lives under the impress of British imperial rule upon their Asante inheritance. Hence, in reviewing and assessing their personal trajectories, I endeavour to give a close-grained account of life courses adjusted and negotiated by agency to the opportunities as well as the limitations of their circumstances.

At one level, both Asante brothers described here might be seen as mediators literally and culturally 'translators' between the old and the new. Figures of this kind are now receiving due scholarly attention from Africanists (Hunt 1999; 2016: Lawrance et al. 2006: Kolapo and Akurang Parry 2007: Newell 2013: Ochonu 2014: M'Bayo 2016) as research moves on beyond the simple and simplistic dualism of collaboration and resistance (Cooper 1994). I am obliged to the suggestive insights afforded by this scholarship, and notably to its basic finding that such persons exercised their greatest influence as colonial regimes were settling in and embedding themselves before the 1920s. Mature colonialism allowed far fewer interstices in which such persons might insert themselves and operate, as both our subjects here discovered in their distinct ways.

The touchstone for many new studies is L'Étrange destin de Wangrin ou les roueries d'un interprète africain (Bâ 1973; 2000; Garane 2013), a masterly piece of cultural reportage in the guise of a novel by the great Malian Fulani intellectual Amadou Hampâté Bâ (1901-91). In this book, the protagonist Wangrin is eventually brought low by a life lived between two alien worlds. The meat of the text, however, is an account of Wangrin's roueries - his devious negotiations, or 'ducking and diving' - as he performs a vertiginous but ultimately doomed balancing act in pursuit of a workable selfhood and status that will afford him due recognition from both the European rulers and the African ruled. Simply put, both of the articles that follow are attempts to illuminate the detailed complexities

\footnotetext{
Tom McCaskie was successively Professor of Asante History at the University of Birmingham and Professor of the History of Africa at SOAS, University of London, until his retirement in 2011. He has worked in and on Asante for fifty years and has published extensively on that subject. Email: tommccaskie@aol.com
} 
of motive, aim and behaviour (including roueries) in two Asante individuals at a very particular historical conjuncture. I have argued for close and intensive biographical work of this sort before (McCaskie 2000: 70-9). The present articles, then, might be termed micro-historical studies, but like all such studies their intention is to supply multum in parvo by juxtaposing and teasing out actor and milieu in all of their multifarious interactions (McCaskie 2015: xi-xxiii).

\section{References}

Bâ, A. H. (1973) L'Étrange destin de Wangrin ou les roueries d'un interprète africain. Paris: Union Générale d'Éditions.

Bâ, A. H. (2000) The Fortunes of Wangrin. Bloomington IN: Indiana University Press.

Cooper, F. (1994) 'Conflict and connection: rethinking colonial African history', American Historical Review 99 (5): 1516-45.

Garane, J. (2013) 'What is new about Amadou Hampaté Bâ? Translation, interpreting, and literary history' in H. Murdoch and Z. Faygal (eds), Francophone Cultures and Geographies of Identity. Newcastle upon Tyne: Cambridge Scholars Publishing.

Hunt, N. (1999) A Colonial Lexicon: of birth ritual, medicalization, and mobility in the Congo. Durham NC: Duke University Press.

Hunt, N. (2016) A Nervous State: violence, remedies and reverie in colonial Congo. Durham NC: Duke University Press.

Kolapo, F. and K. Akurang Parry (2007) (eds) African Agency and European Colonialism: latitudes of negotiation and containment. Lanham MD: University Press of America.

Lawrance, B., E. Osborn and R. Roberts (2006) (eds) Intermediaries, Interpreters, and Clerks: African employees in the making of colonial Africa. Madison WI: University of Wisconsin Press.

M'Bayo, T. (2016) Muslim Interpreters in Colonial Senegal, 1850-1920: mediations of knowledge and power in the lower and middle Senegal River valley. Lanham MD: Lexington Books.

McCaskie, T. (2000) Asante Identities: history and modernity in an African village 1850-1950. Edinburgh and Bloomington IN: Edinburgh and Indiana University Presses.

McCaskie, T. (2015) Asante, Kingdom of Gold: essays in the history of an African culture. Durham NC: Carolina Academic Press.

Newell, S. (2013) The Power to Name: a history of anonymity in colonial West Africa. Athens $\mathrm{OH}$ : Ohio University Press.

Ochonu, M. (2014) Colonialism by Proxy: Hausa imperial agents and Middle Belt consciousness in Nigeria. Bloomington IN: Indiana University Press. 